\title{
Erratum: Nanometre-scale probing of spin waves using single electron spins
}

Toeno van der Sar, Francesco Casola, Ronald Walsworth \& Amir Yacoby

Nature Communications 6:7886 doi: 10.1038/ncomms8886 (2015); Published 7 Aug 2015; Updated 7 Oct 2015

The original version of this Article contained an error in the phrase 'single electron spins' in the title. This has now been corrected in both the PDF and HTML versions of the Article.

(c) (i) This work is licensed under a Creative Commons Attribution 4.0 International License. The images or other third party material in this article are included in the article's Creative Commons license, unless indicated otherwise in the credit line; if the material is not included under the Creative Commons license, users will need to obtain permission from the license holder to reproduce the material. To view a copy of this license, visit http://creativecommons.org/licenses/by/4.0/ 